https://doi.org/10.18485/iipe_response2covid19.2021.ch28

\title{
THE EGYPTIAN BATTLE AGAINST THE CORONAVIRUS: POLICIES AND TOOLS
}

\author{
Raghda Elbahy ${ }^{1}$
}

\begin{abstract}
The Egyptian government applied different policies in its fight against the coronavirus. These policies included social distancing, screening, reducing the attendance of public sector employees, etc. These policies gain importance by taking into account the social dimension by protecting individuals' income, ensuring the provision of strategic goods to the market, and maintaining price stability. These policies conducted community outreach and helped prevent the spread of the coronavirus on the local level on the one hand. And on the other hand, the Egyptian government felt it was important to provide special targeted support to regional countries to fight the pandemic. Hence, it provided medical aid to different countries. The study analyses the Egyptian policies against the coronavirus internally and externally by tracing down the official statements provided by the Ministry of Health, analyzing the main press conferences held by the Egyptian government, and tracing the role played by civil society along with the governmental efforts. The study argues that Egypt has applied integrative tools to combat the coronavirus, whether institutional (crisis management committee) or technological (medical applications, robots, thermographic cameras, etc.) or social (awareness campaigns, poverty protection, etc.). Yet, Egypt faces huge health challenges such as health care reform and vaccine reluctance.
\end{abstract}

Keywords: Pandemic, health care reform, medical assistance, PCR tests, civil society, foreign assistance.

\section{INTRODUCTION}

The coronavirus pandemic, which broke out in late 2019 and wreaked havoc on the global social, economic, and political fronts in the first half of 2020 , remains

\footnotetext{
${ }^{1}$ PhD, Assistant Professor, Political Science Department, Faculty of Economics and Political
} Science, Cairo University, Egypt, elbahy.raghda@feps.edu.eg. 
a central issue on the world agenda. As global healthcare systems stood in the front lines of the battle against a single enemy, uncertainty reigned, and countries attempted to manage the crisis as they waited for a solution to emerge. The pandemic has spread to nearly all countries, causing numerous economic, social, and political repercussions. The Arab Republic of Egypt, like other countries, has attempted to combat the pandemic's harmful impacts through a series of policies and tools aimed primarily at reducing the number of confirmed cases and deaths and arming the healthcare sector with the tools necessary to curb the spread of the pandemic, among other measures. The coronavirus was reflected in Egyptian diplomacy across various foreign policy circles, as Egypt sent medical assistance to various Asian, African, and European countries in parallel with its internal fight. Egypt sent medical assistance to India and Djibouti, for example, in May 2021 (the peak of the third wave in Egypt).

\section{POLICIES ADOPTED AGAINST THE CORONAVIRUS}

Egypt has experienced three waves of coronavirus (the first wave FebruarySeptember 2020, the second wave November 2020-January/February 2021, and the third wave April-July 2021). In the three waves, Egypt adopted several measures to curb the spread of the pandemic during its consecutive waves, such as:

Social distancing: Various official organizations have emphasized the need for social distancing, which is the most essential weapon in preventing the spread of the virus, through a range of Egyptian media. For example, the United Nations Population Fund, in collaboration with the National Council for Women, the Ministry of Health and Population, the World Health Organization, and with the support of the Italian Agency for Development Cooperation, launched an awareness campaign that included a series of videos presented by doctors from various fields. The videos, which featured medical information and advice on the prevention of the coronavirus, were widely shared on many social media platforms. Also notable in this regard are the efforts of the Ministry of Awqaf (Religious Endowments), launched with the slogan of "Prostrates before Mosques" which the Minister of Awqaf Dr. Muhammed Mukhtar Gomaa defined as the preservation of the human soul, as it was one of the most important public purposes of Sharia Islamic law. Within its framework, all mosques carry out a broad campaign for cleanliness and sterilization countrywide, while also reducing commotion, limiting the work of mosques to prayers only, reducing the time of sermons to 10 minutes and implementing social distancing between worshippers, both inside and outside places of worship without crowding (Abdul Hady, 2020). 
Screening: The Egyptian Minister of Health explained that in December 2020, Egypt carried out between 15-20 thousand PCR tests daily in government hospitals, hospitals, and private laboratories. From the beginning of the crisis in early February 2020 till December 2020, the total number of such tests exceeded 300,000 swabs. This is consistent with the statements of the Head of the Department of Central Laboratories of the Ministry of Health, Nancy Al-Gendy, who confirmed that the number of daily swabs carried out at the Ministry's laboratories and hospitals averaged 10,000 swabs. That means that hospitals and private laboratories carry out between 5 and 10 thousand PCR tests daily (Al-Qady, 2020). Every day, the Egyptian Ministry of Health releases a statement detailing the number of people who have died, survived, or been infected. Nevertheless, the statement only includes the number of positive PCRs conducted by the ministry's hospitals only, leaving out the remaining cases, which were discovered by private hospitals and laboratories, and many university hospitals of the Ministry of Higher Education. Some hospitals limit their medical service to cases suspected of the coronavirus, conducting blood and chest scans and corresponding them through a qualified physician without performing the specific swab on the patient. Many patients also seek treatment in private clinics where PCR tests are not permitted (Al-Qady, 2020).

Reducing the attendance of the public sector employees: In the face of the peak of the coronavirus waves, the Egyptian government resorted to reducing the daily presence of public administration staff. It also approved the recruitment of any employee with an exceptional leave, according to the need of work. This took into account, for example, the nature of the health sector, where the leave was handled differently; the Ministry of Health decided to suspend all medical staff leaves at all hospitals and subordinate units. The Ministry of Health also decided to suspend non-mandatory leaves, which included travelling abroad, improving income, or accompanying a spouse (Sammy, 2021). The Ministry of Education and other state bodies allowed those whose employer permits them to work from home to perform their assigned tasks without having to be present in the workplace for the duration of the Prime Minister's decision, provided that the rest of the employees perform the tasks of their jobs alternately, daily or weekly. Any staff member suffering from a chronic illness, according to what is proven in their job file, was granted exceptional leave for the entirety of the duration of this decision, and any staff member with a non-chronic illness was granted the same exceptional leave for the same duration, provided a report issued by a government hospital that he/she is entitled to such leave (Sammy, 2021).

Temporary employment: The Ministry of Manpower disbursed financial grants for irregular employment over three phases; the first phase cost EGP 300 million, 
and around 1.6 million employees benefited from the grants. The second phase began on 21 April 2020, at the same number and cost. The three phases together totalled EGP 800 million (Abdel Nasser, 2020). The regular workers, whose names have been registered, have been subject to conditions to pay the grant in all provinces, centres, and villages, from mail outlets around the Republic, which exceed 4,000. This has taken into account the care of those most in need during the pandemic and the support of irregular employment (Al-Badawi, 2020). The Chief of the Council of Ministers Crisis Chamber confirmed that the government was launching a website, titled "Our people", intending to assist temporary workers who suffer as a result of the state's precautionary measures towards the coronavirus. Also, to achieve a degree of social solidarity between businessmen and temporary workers in order to cope with the damage caused by the spread of the coronavirus, the temporary employment website will include a link to their registration and documentation in parallel with that of the Ministry of Manpower (Abdel Nasser, 2020).

Partial closure: During the peaks of the coronavirus, Egypt took firm steps to ban all conferences and parties in hotels and clubs while also scheduling closure times for shops, malls, coffee shops, and restaurants from $9 \mathrm{pm}$ to limit the spread of the coronavirus. These partial closure procedures were taken to face the three waves of the virus. The Minister of Health stated at one of her official conferences that Egypt has not imposed a policy of full closure like many other countries, which benefited the public interest, and which also depended on the number of infected cases, the degree of government hospital work, the prevention of economic collapse and other economic and social considerations (Sputnik, 2021).

Vaccine production: In Egypt, the Pharco pharmaceutical company announced that it had acquired the rights to produce the Russian vaccine Sputnik $V$ and that the production should begin before the end of 2021. This move coincided with the local production of the Chinese Sinovac vaccine in Egypt, alongside plans of the Egyptian Ministry of Health to produce the European AstraZeneca vaccine later, as well as the ongoing research on a 100\% Egyptian vaccine for its manufacture in the country. Egypt aims to produce a variety of foreign and local vaccines to reach "self-sufficiency", to meet the needs of the citizens, to start exporting abroad, to provide the largest quantity of vaccines, and to vaccinate $70 \%$ of the population (Sky News, 2021, June 18). The Egyptian Ministry of Health recently announced the beginning of the production of Sinovac in Egypt, the first dose of which will be produced within factories of the company holding biologics and vaccines VACSERA. Egypt aspires to produce 40 million doses of that vaccine by the end of 2021, to transfer the entirety of its manufacturing technology to Egypt, to invest in this production to achieve self-sufficiency in vaccines, and to 
export the surplus and manufacturing technology to Arab and African countries. With Egypt's success in producing Sinovac, it will become the first African country to produce an anti-coronavirus vaccine locally (Sky News, 2021, June 18).

\section{EGYPT'S TOOLS TO FIGHT COVID-19}

Towards containing the spread of the novel coronavirus, Egypt deployed different tools, including:

Institutional tools: In response to the COVID-19 pandemic, Egypt established the Higher Committee for the Management of the Coronavirus Crisis headed by the Prime Minister. The committee's regular meetings and constant contact with the Egyptian people is one of its distinctive features. The members of the committee include the Minister of Health and the Minister of Social Solidarity, among other prominent figures. The Financial Regulatory Authority has also been engaged in control efforts aimed at ensuring the high capacity, quality, and effectiveness of pharmaceutical institutions involved in the production of medications and making them available to the public. The Ministry of Health also formed a committee to combat the coronavirus headed by Dr Hossam Hosny. The committee took on several tasks, including declaring coronavirus-related decisions, revealing new symptoms associated with the coronavirus, providing updates on the epidemiological situation and medical condition of some celebrities who got infected with COVID-19, and reviewing treatment protocols in hospitals, among others (Sobhi \& Sami, 2020).

Concomitantly, the Ministry of Higher Education and Scientific Research established the Supreme Committee for Respiratory Viruses headed by Dr Khaled Abdul-Ghaffar, the Minister of Higher Education and Scientific Research. The committee took over several responsibilities, including monitoring the epidemiological situation, reviewing, and discussing scientific research related to the virus, particularly studies on the third wave of the virus, and providing approved recommendations to reduce the rate of infections. Chief among them was a recommendation to establish specialized clinics in university hospitals for the post-coronavirus syndrome, comprising a number of specialties to treat the psychological and medical effects on those recovering from the virus across Egypt (Sobhi \& Sami, 2020).

Civil society: On March 22, 2020, the Egyptian Food Bank (EFB) launched the "Supporting Day Labour Responsibility" campaign in collaboration with 4,365 charities across governorates. For its part, the Misr Al-Kheir Foundation donated 28 ventilators and 2,000 devices for COVID-19 antibody detection and launched the "Your Zakat in Times of Crisis" campaign to provide isolation and quarantine 
hospitals with medical protective equipment and sterilization supplies (AbuSekeen, 2021, April, pp. 181-183). The Al-Orman Charity Association has identified 50 villages, each of which houses about 400 families affected by the coronavirus crisis and provided them with a two-month supply of basic foodstuffs. Moreover, basic food assistance and 10,000 blankets were distributed to COVID-19 isolation hospitals in cooperation with the "Tahya Misr Fund". Concomitantly, the Coptic Evangelical Organization for Social Services (CEOSS) launched several initiatives, including "Thank You Doctors and Medical Teams" in collaboration with the Beni Suef governorate to provide medical staff with an allowance to buy protective tools and face masks. (Abu-Sekeen, 2021, pp. 181-183).

In parallel, the "Ahl Masr Foundation" (AMF) launched an initiative called "People of Egypt Are up to Responsibility" aimed at providing 60 public and university hospitals with medical devices and preventive equipment. The AMF also managed to provide 10 intensive care units and 32 ventilators to hospitals and mounted the "Protecting the White Army, Our Responsibility" campaign, which proved successful in providing protective supplies to medical teams in 63 hospitals across all governorates (Abu-Sekeen, 2021, pp. 181-183). Relatedly, the Red Crescent Society carried out over 1,200 relief campaigns for needy families and villages that were most affected by the repercussions of the pandemic. The Red Crescent convoys have travelled through governorates offering medical examinations and treatment to more than 17,000 beneficiaries affected by COVID19. (Abu-Sekeen, 2021, pp. 181-183).

High-tech tools: Egypt brought its high-tech solutions to the front lines of the coronavirus battle, combining the efforts of the Ministry of Communications and Information Technology (MCIT), the private sector, and innovators, giving rise to a number of innovative robots, novel initiatives, e-applications, and thermal imaging infrared cameras, etc. On 10 June 2020, Mansoura University launched its first domestically manufactured robot designed to provide food and medical supplies to coronavirus patients in isolation hospitals. High-resolution thermal imaging infrared cameras were used in airports for the early detection of suspected cases of COVID-19. As of 5 June 2020, the Egyptian Holding Company for Airport and Air Navigation started installing thermographic cameras in arrival halls at Cairo International Airport. (ElBahy, 2020). Additionally, Egypt launched the Sehat Misr [Egypt's Health] mobile app dedicated to COVID-19 resources and inquiries. The app was introduced to replace the hotline 105 established by the Ministry of Health for the same purpose. The app includes COVID-19 related questions and guidance. Through the app, users can report suspected cases of COVID-19 by clicking the "Report" button and entering the patient's name and national ID number. (EIBahy, 2020). 
The "Tahya Misr Fund": To tackle the repercussions of the coronavirus pandemic, the "Tahya Misr Fund" that was launched in July 2014 by the Presidency of Egypt to activate the previously-announced initiative by the President to establish a fund in support of the economy and to achieve sustained and comprehensive economic growth, moved in two main directions: 1) supporting the medical sector in the face of the virus and 2) supporting vulnerable families and informal workers. Since the launch of the Tahya Misr Fund, it has actively sought follow-up and coordination with the Ministry of Health, Department of Medical Services, and the Egyptian Authority for Unified Procurement, Medical Supply and Technology Management (AUPP). To receive contributions and donations from inside and outside Egypt, the Fund established a bank account "No. 037037 - Responding to crises and disasters" to support the activities of the Fund. The same bank account was also used to receive donations for providing the vaccine for vulnerable groups. Contributions of the Tahya Misr Fund in this respect included providing 1,000 infusion pumps for critical care units, 240 ventilators, 16,000 protective isolation suits, 1 million surgical facemasks, 60,000 N95 masks, 50,000 litres of disinfectants and sterilizers for fever and chest hospitals, and 1,000 virus detectors. Moreover, the Fund co-founded a field hospital at Ain Shams University (Amer, 2021).

Since the outbreak of the pandemic, the Tahya Misr Fund convoys have been involved in distributing foodstuffs under the "Bel Hana Wal Shifa" [Bon Appetite] initiative aimed at supporting vulnerable families and non-regular employment through 6 phases to alleviate the crisis. Through its various phases, the initiative has been successful in providing support to over 8 million citizens across Egypt with a total of 1 million dry ration boxes, 200 tons of meat, 2,150 tons of poultry, 30,600 hot meals, 200 tons of vegetables and fruits, and 133,000 canned food boxes. In coordination with the Ministry of Manpower, the Fund participated in providing one million irregular workers with grants valued at EGP 500 million (Amer, 2021).

Egypt's foreign assistance: On 10 May 2021, three military transport aircraft took off from the East Cairo Air Base carrying large quantities of medical aid provided by the Ministry of Health to India. This step came to alleviate the burden on the Indian people due to the rapid spread of the coronavirus and the high rate of infections and deaths amid a severe shortage of medication, medical supplies, and protective equipment (Othman, 2021). In addition, Egypt built an air bridge for medical supplies and treatment to victims of the Beirut Port explosion of August 2020. In October 2020, Egypt sent tons of milk and medication to Iraq. Egypt also sent medical aid to the Jordanian people in December 2020. Moreover, three aircrafts loaded with large quantities of medical supplies, equipment, and 
milk were sent to Lebanon in the face of the spread of the second wave of the coronavirus (Magdi, 2021). In May 2020, Egypt sent a large virus-aid shipment of sterilization tools to the United States of America following a surge in death rates. The shipment, which consisted of tons of medical devices, carried the label, "From the Egyptian People to the American People", an initiative that was later extended to include other countries (France 24, 2021, May 14). In April 2020, a time when Italy was one of the first hotspots of the pandemic in Europe, Dr Hala Zayed, Egypt's Minister of Health, visited Italy to personally deliver the Egyptian aid, which included protective masks and gloves, to the Italian Minister of Foreign Affairs, Luigi Di Maio (France 24, 2021, May 14). In the aftermath of the outbreak and the declaration of a state of emergency in Italy in April 2020, Egypt was one of the first countries to provide medical aid to the European country to help it contain the crisis after recording the highest infection rate worldwide, exceeding the infection rate in China, where the virus first emerged. For instance, in April 2020, Egypt sent a huge shipment of protective equipment to Britain to help it fight the virus (Russia Today, 2021, May 6).

According to official statements by the Egyptian Minister of Health on May 21,2021 , Egypt is the first African country to provide COVID-19 medical aid to 30 African countries, including Libya, South Sudan, and Congo, among others. Furthermore, according to instructions from President Abdel Fattah Al-Sisi, Egypt sent \$4 million-worth medical aid to African countries to help contain the coronavirus pandemic. In a related context, Egypt sent aid to Sudan on board two military aircraft that took off from the East Cairo Air Base carrying large quantities of food aid to contribute to relieving the burdens on the Sudanese people. (Russia Today, 2021, May 6).

\section{EGYPT'S CHALLENGES}

Despite the multiple policies and tools Egypt has adopted and used to curb the spread of the COVID-19 pandemic, numerous challenges have emerged, such as:

Reluctance to receive vaccines: Egypt conducted serious negotiations with the three companies that produce coronavirus vaccines - China's Sinopharm, US Pfizer, and British AstraZeneca - to get enough vaccines to vaccinate $40 \%$ of Egypt's 100 million population by the end of 2021. Egypt has not relied on a single vaccine in response to COVID-19. Of course, the negotiations required meetings with representatives of Pfizer USA, UAE, and Egypt in the presence of the scientific committee observing the fight against the COVID-19 and representatives of the Unified Procurement Authority and Egyptian Drug Authority to consult with on the supply of the company's vaccines after the company presents its financial 
offer. It also required the approval of the Egyptian Drug Authority, which approved the licensing of the Chinese Sinopharm vaccine for emergency use. (Al Arabiya.net, 2021, January 3).

Although the state launched a website to register the data of those who want to receive the available anti-COVID-19 vaccines, a state of reluctance to register has been observed among both doctors, although they are the most in need of vaccination, and citizens. The Minister of Health Hala Zayed stated that only 50\% of medical staff have registered for the anti-COVID-19 vaccine, while $100 \%$ were targeted, and $40 \%$ of the registered medical staff failed to appear (Omran, 2021). Undoubtedly, citizens' reluctance to receive the vaccine did not occur only in Egypt but also in most countries in the world. This was attributed to social media, fear of side symptoms and long-term effects of the vaccine, especially with insufficient research, and the AstraZeneca vaccine linked to blood clots. To address these and other concerns, the Egyptian President, Prime Minister Mustafa Madbouli, and several ministers have published images of their vaccination to encourage citizens to receive the vaccine and urge them to register and get vaccinated. Several officials, primarily the deputy of the Health Committee in the House of Representatives Mahmoud Abu Khair, have consistently stressed the need to take the vaccine to avoid the severe symptoms affecting citizens in the third wave of COVID-19, especially since all vaccines in Egypt are guaranteed and tested worldwide and in Egypt (Omran, 2021).

The private sector: There have been negotiations concerning the participation of the private sector in the COVID-19 vaccination campaign. The Proposals and Complaints Committee of the House of Representatives has approved a proposal on private sector participation in the vaccination system, provided that private sector institutions receive the approval of the Egyptian Drug Authority. A senior executive of the Ministry of Health confirmed in a statement that some steps are being taken by the Ministry in this direction. There are procedures currently taking place for contracting with two companies to provide the vaccine to citizens, as there is room for any company to apply to participate under the standards of the Ministry of Health. There is no doubt that this step requires precise study. It is well-known that vaccines and treatments are provided free of charge in times of pandemics and health epidemics under the supervision of the Health Ministry. So, opening the door to the private sector will thus create inequality and commodification at a time of the global pandemic. There will be two vaccination systems, one free of charge with a waiting list for those who want to get it through government outlets, and the other is with fees for those who want to be vaccinated quickly (Ghanam \& Azzab, 2021). 
Economic considerations: Egypt faced a challenge in terms of providing strategic stocks of certain food commodities, particularly as some consumption patterns changed with the spread of COVID-19. This has required strenuous efforts on the part of the Ministry of Supply and Internal Trade, represented by the General Authority for Supply Commodities and the Ministry of Agriculture and Land Reclamation, to expand wheat cultivation through; the contract farming system, procedures for early contracting with external actors to ensure the supply of appropriate quantities, provision of appropriate import ports and wheat collecting centres, in particular the establishment of modern metal silos and the development and upgrading of the list, and ensuring a strategic stockpile that meets the demand of some 70 million citizens on an estimated 128 billion loaves ( 5 loaves per person per day) (The Nile Letter, 2020, March 29). The Ministry of Agriculture's strategic crop production plans had to be fully coordinated with the Ministry of Supply and Internal Trade's import plans to determine the extent of the food gap and the volume of total imports to fill the gap at the level of the most important agricultural products. It was also necessary to strengthen the financial capacity of the Holding Company for Food Industries, which is entrusted with the provision of food commodities, so that it could import the requirements of the domestic market for strategic goods, primarily sugar, oil, and rice, besides completing sugar and dry food packaging factory chains, and others (The Nile Letter, 2020, March 29).

Reforming the health sector: The majority of world countries, including Egypt, have embarked on a serious scheme to reform the health sector. It is a serious challenge, especially since it requires progressive reform in partnership with various bodies in the governmental, non-governmental and private sectors to provide Egyptians with quality services. There is a need to improve the mental image of all healthcare providers, continue medical training, promote a positive working environment, and scientifically develop medical and nursing staff accommodation in government hospitals to attain this goal. There is no doubt that special legislation is required to prepare for the launch of The National Project for Model Hospitals in all governorates of the Republic in conjunction with implementing the National Project for the Unified Health Insurance (Magdi, 2018).

\section{CONCLUSION}

Overall, the Egyptian battle against the coronavirus was a successful one. Egyptian policies took into account the social dimensions and health implications of the coronavirus without having a severe impact on the Egyptian economy, with the acknowledgement of international organizations. This is particularly important 
compared to several leading international experiences that have either strained the health system or strained the economic system. An increase in the population of over 100 million has undoubtedly imposed constraints that undermine social distancing policies, require large-scale medical examinations, and require a doubling of the budget of the Ministry of Health.

However, the use of innovative tools and reliance on citizen awareness, various technological tools, and the creation of several websites (for citizens who want to register to receive a vaccine or temporary employment, etc.), the concerted efforts of civil society and the creation of crisis management committees have all contributed to managing the COVID-19 crisis and mitigating its negative impact not only at home but also abroad through Egyptian medical diplomacy.

Some of the challenges that Egypt faces are indeed global, particularly the reluctance to receive vaccines, the health system reformation, and the difficulty in obtaining vaccines. On the other hand, there are purely Egyptian challenges stemming from the specificity of the Egyptian situation, such as those relating to the potential participation of the private sector in the vaccination process and the increasing dependence on certain crops, primarily wheat. In both cases, civil society is joining forces with government policies to face these challenges, giving priority to the Egyptian citizen as the engine of development.

Yet, vaccine reluctance remains the biggest challenge. It can be attributed to the lack of trust in the vaccine's efficacy and safety, the fears of the side effects and long-term impacts, the spread of rumours and long waiting lists. Taking into account these reasons, a total of 10,418,988 million vaccine doses has been administered as of 5 September 2021 (according to the World Health Organization). So, despite the effective policies, the national vaccination plan must be developed, and a targeted awareness campaign must be launched. This proves that the battle against the coronavirus is not only a battle of the Egyptian government to be fought, but also a battle that necessitates the efforts of civil society, the citizens, and the official bodies, altogether. The media, electronic press, and social media must be fully utilized.

\section{REFERENCES}

Abdul Hady, S.(2020, December 24). "Do mosques close their doors after the increase in Corona injuries?... the Minister of Waqf answers". Al-Ahram, retrieved from https://gate.ahram.org.eg/News/2548502.aspx. Accessed 2 June 2021. 
Al-Qady, A. (2020, December 30). "In settlement of the controversy, how does the Egyptian Ministry of Health calculate Corona injuries?". Sky News Arabia, retrieved from https://cutt.ly/QmecBhv. Accessed 22 June 2021.

Sammy, M. (2021, January 4). "To combat Corona... Learn about the rotation schedules for the attendance of state employees". Masrawy, retrieved from https://cutt.ly/umevSfD. Accessed 2 June 2021.

Al-Badawi, M.(2020, June 23). "Saafan: Corona's grant for temporary workers has cost the state 800 million pounds so far".Al-Watan, retrieved from https://cutt.ly/kmevLUd. Accessed 19 June 2021.

Abdel Nasser, M. (2020, April 1). “Our People”... a new website for the government to document and register temporary workers affected by Corona". Al-Watan, retrieved from https://cutt.ly/Fmev1Uu. Accessed 3 June 2021.

Sputnik. (2021, April 4). "Egyptian Minister of Health, Hala Zayed, resolved the controversy around imposing a partial ban". Sputnik, retrieved from https://cutt.ly/1mebzrj. Accessed 3 June 2021.

Sky News. (2021, June 18). "Egypt... A complete plan for self-sufficiency of antiCorona vaccines". Sky News, retrieved from https://cutt.ly/HmebHtW. Accessed 18 June 2021.

Abu-Sekeen, H. (2021). "The role of civil society in Egypt in addressing the coronavirus pandemic", Democracy Magazine, 82, pp. 181-183.

ElBahy, R. (2020, June 21). "Addressing the Coronavirus: 10 Out of the Box Egyptian technological solutions". Egyptian Center for strategic Studies (ECSS), retrieved from https://cutt.ly/Mmem4ei. Accessed 21 June 2021.

Amer, A. (2021, June 21). "Al-Ahram Gate monitors Tahya Misr Fund year-round efforts in the face of the coronavirus". Al-Ahram, retrieved from https://cutt.ly/ vmeQ7aG. Accessed 2 June 2021.

Sobhi, M. \& Sami, C. (2021, June 14). "Higher education recommends establishing specialized clinics in university hospitals for post-Corona syndrome". Al-Youm 7, retrieved from https://cutt.ly/nmeEasC. Accessed 21 June 2021.

Othman, D. (2021, 10 May). "Egyptian medical aid to India to combat the coronavirus". Al-Masry Al-Youm, Retrieved from https://cutt.ly/5meEchD. Accessed 2 June 2021.

Magdi, A. (2021, February 9). "Most Recently Sudan: Egypt's aid to the world during the Corona pandemic does not stop", Al-Watan, retrieved from https://cutt.ly/9meEmoy. Accessed 2 June 2021. 
France 24. (2021, 14 May). Egypt leverages 'soft power' through medical aid in pandemic. France 24, retrieved fromhttps://cutt.ly/Cmagmll. Accessed 2 June 2021.

Russia Today. (2021, May 6).“An Egyptian military aircraft delivers a shipment of medical supplies to Tunisia", Russia Today, retrieved from https://cutt.ly/ RmeRnUN. Accessed 2 June 2021.

Magdi, M. (2018, July 15).“Minister of Health: Gradually reforming the health system. Our goal, Citizen's Satisfaction".Al-Watan, retrieved from https://cutt. ly/2meR2IN.Accessed 26 May 2021.

Al Arabiya.net (2021, January 3)."Egypt contracts on 100 million doses of the Covid-19 vaccine". Al Arabiya.net, Retrieved from https://cutt.ly/wmeTl5J. Accessed 2 June 2021.

Omran, A. (2021, May 24). "The Secret of Egyptians and Medical Staff Reluctance to Receive Corona Vaccine". Al Nabaa, retrieved from https://cutt.ly/CmeTmxt. Accessed 2 June 2021.

Ghanam A. \& Azzab A. (2021, June 19)."Follow-up to the Most Outstanding Challenges on the File of Anti-Covis-19 Vaccines". Shrouk, retrieved from https://cutt.ly/BmeTAai. Accessed 2 June 2021.

The Nile Letter. (2020, March 29)."Identifying Commodity Stock in Egypt”. The Nile Letter, retrieved from https://cutt.ly/RmeYwLd. Accessed 2 June 2021. 